Acta vet. scand. 1961, 2, 323-329.

From the Veterinary Bacteriological Laboratory, Västerås, and the State Bacteriological Laboratory, Stockholm, Sweden.

\title{
TREATMENT OF \\ BOVINE STAPHYLOCOCCAL MASTITIS WITH STAPHYLOCOCCAL TOXOID
}

By

\author{
H. Thörne \& G. Wallmark
}

Staphylococci are a relatively common bacteriological finding in bovine mastitis. In some herds staphylococcal mastitis is the predominating infection $(13,14)$. Pathogenic staphylococci generally settle permanently, and the possibilities of controlling the infection by antibiotic therapy are, on the whole, limited in such a herd. In certain staphylococcal infections in man positive results have been obtained by immunization (2). Immunization has also been tried in animals for prophylactic and therapeutic purposes, for instance in staphylococcal mastitis in cows and sheep $(1,5,6,7,8,9,10,11)$. Toxoid alone, or toxoid together with killed bacteria, was used in these trials. The value of the method is, as yet, not fully known, however.

The purpose of the investigation presented here was to study the prophylactic and therapeutic effect on bovine staphylococcal mastitis of treatment with a toxoid that has been advantageously used in staphylococcal infections in man.

\section{MATERIAL AND METHODS}

A herd $(K)$ consisting of 40 cows and about 20 heifers and young cattle more than 1 year of age was used. The investigation was started in the spring of 1958 and completed in the spring of 1961 . Before the start the herd had for 5 years been subjected to halfyearly clinical and bacteriological examinations of the udder. It had thus been found that about $50 \%$ of the cows had mastitis, in most cases caused by pathogenic staphylococci. Only a few cases of streptococcal or pseudomonas infection occurred. The 
isolated staphylococci were coagulase-positive, fermented mannitol and produced both $\alpha$ and $\beta$ toxin. In specimens of udder secretion from a quarter with clinically and bacteriologically verified staphylococcal mastitis staphylococci had been isolated on repeated occasions. Spontaneous healing occurred only in exceptional cases, but, in general, an equilibrium was established after varying lengths of time. This equilibrium could apparently be upset for various reasons: several cases of acutized infection occurred every year.

Clinical methods. Clinical examination was made every half year. The udders were inspected and palpated. Quarter samples were examined in a strip cup and subjected to the Whiteside test (WT), using the technique described by Murphy \& Hanson (3).

Bacteriological methods. Bacteriological examination was carried out half-yearly at the same time as the clinical examination. From milk samples taken with the usual precautionary measures, $0.1 \mathrm{ml}$. was inoculated to $5 \%$ cattle-blood agar. Reading was done after incubation at $37^{\circ} \mathrm{C}$ for 24 and 48 hours. In addition, samples incubated by the method devised by Hotis were inoculated to cattle-blood agar and read after 24 and 48 hours.

From each sample in which staphylococci were found, a number of colonies were subcultured for further examination. Toxoid treatment. Every other animal out of the total of 61 over 1 year of age was treated with toxoid, and the others were used as controls. The treated animals and the controls were kept together in the same stable, standing in their ordinary stalls and being moved within the stable according to the milk yield. The toxoid was the purified aluminium-adsorbed staphylococcal toxoid designed for use in man, prepared by the State Bacteriological Laboratory, Stockholm. It was given in series of subcutaneous injections of 1,2 , and $5 \mathrm{ml}$. at intervals of 1 week. The series of injections were given twice every year, in the autumn and the spring, throughout the period of investigation.

Serological method. The antistaphylolysin titre (ASta) in bloodserum was determined by the method described earlier (12), which in essentials agrees with the method devised by Packalén \& Bergqvist (4). Blood specimens were taken four times a year from all the toxoid-treated animals: immediately before the first injection of toxoid, and 10-12 days after the last injection in each series. 


\section{RESULTS}

During the 3 years covered by the study 17 cows of the herd were taken to slaughter. The investigation could therefore be carried through with 23 cows. Of these, 11 were treated with toxoid, and 12 were used as controls. Over the same period 21 cows, which at the beginning of the investigation had been heifers or young cattle, were added to the material. Of these 21 cows 11 received toxoid and 10 were used as controls.

Antistaphylolysin titres. The 11 toxoid-treated cows had an initial ASta titre that varied between $<0.36$ and 11 units per ml. of serum, while all the heifers had a titre of $<0.36$ units. The toxoid treatment was in most cases followed by a significant rise of ASta, as will be seen from Tables I and II. About 5 months later, immediately before the next series of injections, the titres had fallen to values that only slightly exceeded the initial ones. Clinical effect. In the toxoid-treated group of 11 cows a total of 21 quarters in 9 cows showed clinical and bacteriological evidence of staphylococcal mastitis at the beginning of the investigation. At the completion of the study all the 9 cows were still infected, but the total number of infected quarters had fallen to 13 (Table I). During the period of investigation 9 quarters healed and new infection was demonstrated in one quarter. In one cow (no. 3), which at the beginning of the investigation had staphylococcal mastitis with severe secretory changes (WT ++++ ) in all four quarters, staphylococci were 2 years later recovered from one quarter only (WT ++ ). This cow was then taken to slaughter for some other reason. The ASta titre had for more than a year been 22-32 units per ml. of serum.

The control group consisted of 12 cows. In 5 of these staphylococcal infection was at the beginning of the investigation present in 9 quarters. At the completion of the investigation 8 cows were infected in 18 quarters. In no quarter had healing occurred. New infection during the period of investigation was demonstrated in 9 quarters.

In the toxoid-treated group no case of acutized mastitis occurred during the course of the study. In the control group, on the other hand, 3 cases of acutized staphylococcal mastitis were seen.

Out of the 11 cows which at the beginning of the investigation were heifers or young cattle and in which treatment had started before the first calving, 3 showed signs of staphylococcal mastitis 
T a b l e I. Antistaphylolysin titres (IU/ml. blood-serum) in relation to injections of toxoid in 11 cows.

\begin{tabular}{|c|c|c|c|c|c|c|c|c|c|c|}
\hline \multirow{2}{*}{$\begin{array}{l}\text { No. of } \\
\text { cow }\end{array}$} & \multicolumn{2}{|c|}{ Series 1} & \multicolumn{2}{|c|}{ Series 2} & \multirow[t]{2}{*}{$\begin{array}{c}\text { Series } 3 \\
\text { after }\end{array}$} & \multirow[t]{2}{*}{$\begin{array}{c}\text { Series } 4 \\
\text { after }\end{array}$} & \multirow[t]{2}{*}{$\begin{array}{l}\text { Series } 5 \\
\text { after }\end{array}$} & \multirow[t]{2}{*}{$\begin{array}{l}\text { Series } 6 \\
\text { after }\end{array}$} & \multicolumn{2}{|c|}{$\begin{array}{l}\text { Number of quarters } \\
\text { with staphylococcal } \\
\text { infection }\end{array}$} \\
\hline & $\begin{array}{l}\text { be- } \\
\text { fore }\end{array}$ & $\begin{array}{l}\text { af- } \\
\left.\text { ter }^{1}\right)\end{array}$ & $\begin{array}{l}\text { be- } \\
\text { fore }\end{array}$ & $\begin{array}{l}\text { af- } \\
\text { ter }\end{array}$ & & & & & $\begin{array}{l}\text { before } \\
\text { treat- } \\
\text { ment }\end{array}$ & $\begin{array}{c}\text { at comple- } \\
\text { tion of } \\
\text { treatment }\end{array}$ \\
\hline 1. & 4.0 & 8.0 & 2.8 & 4.0 & 8.0 & 5.6 & 8.0 & 8.0 & 3 & 2 \\
\hline 2. & 4.0 & 32.0 & 8.0 & 22.0 & 16.0 & 16.0 & 11.0 & 16.0 & 2 & 2 \\
\hline 3. & 11.0 & 22.0 & 8.0 & 16.0 & 32.0 & 22.0 & 32.0 & & 4 & 1 \\
\hline 4. & 2.8 & 8.0 & 1.4 & 8.0 & 5.6 & 8.0 & 11.0 & 11.0 & 3 & 1 \\
\hline 5. & 2.0 & 8.0 & 4.0 & 8.0 & 8.0 & 11.0 & 8.0 & 11.0 & 2 & 1 \\
\hline 6. & 2.0 & 4.0 & 4.0 & 8.0 & 4.0 & 8.0 & 8.0 & 5.6 & 2 & 1 \\
\hline 7. & $<0.36$ & 4.0 & 0.5 & 2.0 & 0.7 & 5.6 & 5.6 & 5.6 & 2 & 1 \\
\hline 8. & 4.0 & 2.8 & 1.4 & 2.8 & 5.6 & 2.0 & 4.0 & 4.0 & 2 & 3 \\
\hline 9. & 0.5 & 4.0 & 1.0 & 4.0 & 4.0 & 2.0 & 5.6 & 4.0 & 1 & 1 \\
\hline 10. & $<0.36$ & 2.0 & 0.36 & 1.4 & 2.0 & 11.0 & 8.0 & 8.0 & 0 & 0 \\
\hline 11. & 0.5 & 4.0 & 0.5 & 2.8 & 4.0 & 2.0 & 4.0 & 5.6 & 0 & 0 \\
\hline
\end{tabular}

1) 10-12 days after the last injection in the series of 1,2 and $5 \mathrm{ml}$. subcutaneously at weekly intervals. Two series were given each year.

T a b l e I I. Antistaphylolysin titres (IU/ml. blood-serum) in relation to toxoid treatment in 11 animals which were heifers at the beginning of the study.

\begin{tabular}{|c|c|c|c|c|c|c|c|c|c|}
\hline \multirow{2}{*}{$\begin{array}{l}\text { No. of } \\
\text { cow }\end{array}$} & \multicolumn{2}{|c|}{ Series 1} & \multicolumn{2}{|c|}{ Series 2} & \multirow{2}{*}{$\begin{array}{c}\text { Series } 3 \\
\text { after }\end{array}$} & \multirow{2}{*}{$\begin{array}{c}\text { Series } 4 \\
\text { after }\end{array}$} & \multirow{2}{*}{$\begin{array}{c}\text { Series } 5 \\
\text { after }\end{array}$} & \multirow{2}{*}{$\begin{array}{l}\text { Series } 6 \\
\text { after }\end{array}$} & \multirow{2}{*}{$\begin{array}{l}\text { Number of quar } \\
\text { ters with staphy } \\
\text { lococcal infection } \\
\text { at completion } \\
\text { of study }\end{array}$} \\
\hline & before & after $\left.{ }^{2}\right)$ & before & after & & & & & \\
\hline 12. & $<0.36$ & 4.0 & 0.5 & 4.0 & 8.0 & 1.4 & 2.0 & 5.6 & 0 \\
\hline 13. & $<0.36$ & 4.0 & 0.5 & 5.6 & 1.4 & 2.0 & 4.0 & 4.0 & 0 \\
\hline 14. & $<0.36$ & 11.0 & 4.0 & 8.0 & 4.0 & 5.0 & 5.6 & 8.0 & 0 \\
\hline 15. & $<0.36$ & 4.0 & 2.8 & 4.0 & 4.0 & 11.0 & 4.0 & 2.0 & 0 \\
\hline 16. & $<0.36$ & 4.0 & $<0.36$ & 0.5 & 0.5 & 0.7 & 1.4 & 4.0 & 2 \\
\hline 17. & $<0.36$ & 4.0 & $<0.36$ & 2.0 & 1.7 & 1.4 & 2.8 & 4.0 & 0 \\
\hline 18. & $<0.36$ & 1.0 & $<0.36$ & 1.4 & 0.5 & 1.4 & 1.4 & 5.6 & 2 \\
\hline 19. & $<0.36$ & 2.0 & $<0.36$ & 2.8 & 2.8 & 1.4 & 4.0 & 2.8 & 0 \\
\hline 20. & $<0.36$ & 1.0 & 0.5 & 2.8 & 2.0 & 2.0 & 0.7 & 2.8 & 2 \\
\hline 21. & $<0.36$ & 5.6 & 0.5 & 4.0 & 5.6 & 4.0 & 5.6 & 2.8 & 0 \\
\hline 22. & $<0.36$ & 4.0 & 0.5 & 5.6 & 4.0 & 4.0 & 5.6 & 5.6 & 0 \\
\hline
\end{tabular}

2) See foodnote to Table I. 
in a total of 6 quarters at the completion of the investigation (Table II). In the corresponding control-group of 10 animals 4 showed at that time signs of staphylococcal mastitis, likewise in 6 quarters.

\section{DISCUSSION}

Staphylococcal mastitis in cows is a common disease, which offers great therapeutic problems. It generally runs a chronic course. The response to antibiotic treatment is usually poor. The infection seems to spread from one cow to another by means of the milking equipments etc. In the present study an attempt has been made to control this infection by means of immunization of the animals with a staphylococcal toxoid.

The therapeutic effect of such an immunization was studied in a group of cows. Although the material was small, the treatment seemed to have an obvious effect. The number of infected quarters among the treated animals fell from 21 to 13 , as compared to a rise from 9 to 18 quarters in a similar control group that otherwise was treated in an identical way. In this group of animals the toxoid treatment thus seemed to have a therapeutic as well as prophylactic effect on staphylococcal infections.

On the other hand in another group of animals which at the beginning of the immunization were heifers, no prophylactic effect was observed. Also this group of animals was rather small, however.

It would have been expected that an immunization which was started before the animals had been exposed to the risk of acquiring mastitis, and which was maintained during this period, should have produced the most favourable results. One explanation may be that the heifers gave a lower antistaphylolysin response. It is possible that immunization with a vaccine prepared from staphylococci with a direct relationship to bovine mastitis might have a better effect. Trials with such a vaccine are in progress.

Irrespective of the possible effect of active immunization, other measures are also necessary for controlling staphylococcal mastitis, such as improvement of the general hygiene and the sanitary conditions in milking, and elimination of environmental factors that lower the animals resistance. 


\section{REFERENCES}

1. Derbyshire, J. B.: J. comp. Path. 1960, 70, 222.

2. Lithander, A.: Svenska Läkartidn. 1956, 53, 3357.

3. Murphy, J. M. and Hanson, J. J.: Cornell Vet. 1941, 31, 47.

4. Packalén, T. and Bergquist, S.: Acta. med. scand. 1947, 127, 291.

5. Pearson, J. K. L.: J. Dairy Res. 1959, $26,9$.

6. Pillet, J., Girard, O., Dutheil, H. and Orta, B.: Ann. Inst. Pasteur $1959,96,365$.

7. Pillet, J., Girard, O., Dutheil, H. and Orta, B.: Ann. Inst. Pasteur 1959, 96, 591.

8. Ramon, G., Richou, R., Julienne, P. and Jacquet, J.: Bull. Off. Int. Epiz. 1953, 39, 610.

9. Richou, R. and Holstein, G.: Rec. Méd. Vét. 1941, 117, 329.

10. Richou, R. and Thieulin, G.: Rec. Méd. Vét. 1955, 131, 73.

11. Slanetz, L. W., Bartley, Clara and Allen, F. E.: J. Amer. vet. med. Ass. 1959, 134, 155.

12. Thörne, H.: Nord. Vet.-Med. 1958, 10, 63.

13. Thörne, H.: Nord. Vet.-Med. 1958, 10, 309.

14. Thörne, $H$. and Wallmark, G.: Acta vet. scand. 1960, 1, 114.

\section{SUMMARY}

Every other animal in a herd was treated with staphylococcal toxoid for 3 years. In the herd there occurred a relatively great number of cases of staphylococcal mastitis. The treatment of already infected cows had seemingly a flavourable effect, whereas the treatment of heifers did not give the protection against staphylococcal infection that had been expected. Active immunization might be a valuable weapon to control staphylococcal mastitis, but other measures are also necessary.

\section{ZUSAMMENFASSUNG}

Behandlung der Staphylokokkenmastitis mit Staphylokokkentoxoid.

Jedes zweite Tier in einem Bestande wurde während einer Zeit von 3 Jahren mit Staphylokokkentoxoid behandelt. In diesem Bestande kam eine verhältnismässig grosse Anzahl von Staphylokokkenmastitiden vor. Die Behandlung bereits infizierter Kühe hatte augenscheinlich einen günstigen Effekt, dagegen ergab die Behandlung von Sterken nicht den erwarteten Schutz gegen Staphylokokkeninfektion. Bei der Bekämpfung von Staphylokokkenmastitiden dürfte aktive Immunisierung wertvoll sein, aber auch andere Massnahmen sind notwendig. 


\section{SAMMANFATTNING}

Behandling av den bovine staphylokockmastiten med staphylokocktoxoid.

Vartannat djur i en besättning behandlades med stafylokocktoxoid under 3 års tid. I besättningen förekom ett relativt stort antal stafylokockmastiter. Behandlingen av redan infekterade kor hade en till synes gynnsam effekt, under det att behandlingen av kvigor inte gav det skydd mot stafylokockinfektion, som förväntats. Aktiv immunisering torde vara värdefull vid bekämpandet av stafylokockmastiter, men även andra åtgärder äro nödvändiga.

(Received September 5. 1961). 